\title{
Impact of high residential density on the building technology, HVAC systems, and indoor environment in Swedish apartments
}

\author{
Akram Abdul Hamid ${ }^{1 *}$, Jenny von Platten ${ }^{1,2}$, Kristina Mjörnell ${ }^{1,2}$, Dennis Johansson ${ }^{3}$ and Hans Bagge ${ }^{1}$ \\ ${ }^{1}$ Division of Building Physics, Lund University; akram.abdul_hamid@byggtek.lth.se \\ ${ }^{2}$ RISE Research Institutes of Sweden; 41258 Gothenburg, Sweden; kristina.mjornell@ri.se \\ ${ }^{3}$ Division of Building Services, Lund University; dennis.johansson@hvac.lth.se
}

\begin{abstract}
During the last few years, there has been an increased number of overcrowded apartments, due to increased migration but also housing shortage in general, particularly in the suburbs to major cities. The question is how the indoor environment in these apartments is affected by the high number of persons and how the problems related to high residential density can be overcome. This paper aims to specify the problem by investigating and analysing the technical parameters influenced by residential density in Swedish apartments built between 1965-1974. To map the situation, 11 interviews with employees at housing companies were conducted. Based on extreme conditions described in the interviews, simulations of the indoor climate and moisture risks at some vulnerable parts of constructions were made. Simulations were focused on moisture loads and $\mathrm{CO}_{2}$ concentrations as functions of residential density and ventilation rate. Finally, measures to combat problems associated to overcrowding are suggested. The aim is that the results should be used by authorities to formulate incentives and/or recommendations for housing companies to take actions to ensure a good indoor environment for all, irrespective of residential density conditions.
\end{abstract}

\section{Introduction}

In Sweden, over a million homes were built during 19651974 , the so called "million homes programme", in order to solve the housing shortage and abolish poor housing standards [1]. During the last few years, the number of residents in many apartments in these buildings, especially in suburbs to major cities, has increased due to housing shortage in general but also due to immigration. The question is how the increased number of residents, and thus the excess moisture load and increased indoor air pollution, will affect the risk of poor indoor air quality (IAQ) and moisture damage. The apartments from the million homes programme were designed for a normal-sized family of two to four persons with natural ventilation in many of the buildings [2], and in some buildings mechanical exhaust ventilation systems [2] primarily designed to ensure an air exchange in the apartment according to the Swedish building regulations at that time. However, the ventilation in many of these apartments is already insufficient at normal residential load compared to modern standards, since approximately half of them have air change rates lower than $0.5 \mathrm{ac} / \mathrm{h}$ [2], which approximately corresponds to modern requirements of $0.35 \mathrm{l} /\left(\mathrm{s} \cdot \mathrm{m}^{2}\right)$. A well-functioning ventilation system in buildings is a prerequisite both for achieving good IAQ and thermal comfort, and $\mathrm{CO}_{2}$ is generally accepted as an indicator for the IAQ since other pollutants correlate to $\mathrm{CO}_{2}$ concentrations. The Pettenkoefer limit for $\mathrm{CO}_{2}$ of $1000 \mathrm{ppm}$ is generally regarded as a limit to not be exceeded in order to maintain good IAQ. However, a recent study showed negative effects on health at much lower $\mathrm{CO}_{2}$ concentrations than previously known [3].
Already in 1993, Markus [4] stated that overcrowding and inadequate ventilation increase the interior moisture load. To some extent, high residential density might lead to an increase of moisture loads due to increased presence of people as well as an increase in moisture-generating activities such as cooking, washing and showering, which may affect the building materials and systems. It might also restrict the placement of furniture, for instance if furniture or curtains are placed against poorly insulated external walls, the temperature on the interior surface of the wall might decrease, which in combination with a high moisture load may result in high relative humidity $(\mathrm{RH})$, and maybe even condensation. Specifically, on biological materials the risk for microbial growth is significant when the $\mathrm{RH}$ exceeds $75 \%$ at room temperature [5]. Moreover, according to results from interviews conducted by Boverket [6], high residential density leads to an increased number of furniture and other items in the apartment, which makes it more difficult to maintain a clean indoor environment, which can affect the IAQ and lead to respiratory diseases.

A solution for dealing with the increased loads in the indoor air could be a higher ventilation rate, which should decrease the moisture loads on the building materials and avoid high concentrations of indoor pollutants. To force the ventilation to higher levels than the system is designed for is probably possible with existing fans, but it is likely to cause noise and draught indoors and will increase the energy use considerably. In cold climates, the ventilation energy use will approximately double if the residential load is doubled and the air change rate matches the load, but the absolute increase can be considerably reduced if heat-recovery is installed [7].

\footnotetext{
* Corresponding author: akram.abdul_hamid@byggtek.lth.se
} 
To our knowledge, there is a lack of research dealing with the impact of high residential density on the building technology, the HVAC systems, and the indoor environment. There is also a gap regarding how to design and manage apartments as a function of residential density. As a starting point, this paper aims to contribute with knowledge on the impact of high residential density by investigating the nature and scope of issues related to overcrowded apartments and analyse the technical parameters that can be influenced by a high residential density. To do so, a mapping of issues in overcrowded apartments is done through a number of interviews with housing caretakers. In addition, to exemplify and give orders of magnitudes of building physical phenomena (e.g. condensation on the interior surface of external walls) that occurs at high residential loads, hygrothermal simulations are conducted. The aim of this study is to provide valuable input to authorities and help them formulate incentives and/or recommendations for housing owners to implement measures, such as applicable ventilation technology, that improves the IAQ and ensure a good indoor environment for all, irrespective of residential density conditions.

\section{Methods}

\subsection{Semi-structured interviews}

The first part of the study consisted of 11 semistructured interviews with property managers, housing caretakers, an energy and environment manager, and one tenant service manager at their workplace. At six of the interviews, two of the authors were present; one leading the conversation based on pre-formulated questions and the other making notes and breaking into the conversation. The other five interviews were conducted by one author only. The pre-formulated questions covered areas such as:

Type of buildings, biggest challenges with the buildings, type of households, number of residents in each apartment, problems with high/low residential density, residents experience of the indoor environment, type of complaints, performed measures to remedy complaints, moisture damages, type of ventilation system, measures to adapt the ventilation system, residents' own measures or interventions in the apartment and possible consequences of that, data on consumption of energy for heating, DHW, electricity, monitoring of temperature and $\mathrm{RH}, \mathrm{HH}$ electricity data, registers of residents per apartment, possibility to adjust apartment to number of residents, the effect of high residential density on need of maintenance and wear of drain/sewage, increased wear and tear of interior materials and finally the interviewees' own suggestions on possible technical solutions to overcome problems caused by high residential density.

Table 1. Type of company, location of residential area and role of interviewees. Major city $>200,000$ inhabitants. Middle size cities 50,000 - 200,000 inhabitants. Small cities $<50,000$ inhabitants.

\begin{tabular}{|c|c|c|}
\hline $\begin{array}{l}\text { Type of } \\
\text { housing } \\
\text { company }\end{array}$ & Location & $\begin{array}{c}\text { Role of } \\
\text { interviewees }\end{array}$ \\
\hline Public & $\begin{array}{c}\text { Suburb of major city in } \\
\text { west of Sweden }\end{array}$ & 3 caretakers \\
\hline Public & $\begin{array}{c}\text { Suburb to major city in } \\
\text { west of Sweden }\end{array}$ & 1 caretaker \\
\hline Public & $\begin{array}{l}\text { Suburb to major city in } \\
\text { west of Sweden }\end{array}$ & 1 caretaker \\
\hline Public & $\begin{array}{l}\text { Middle size city in } \\
\text { south of Sweden }\end{array}$ & $\begin{array}{l}1 \text { tenant service } \\
\text { manager }\end{array}$ \\
\hline Private & $\begin{array}{l}\text { Suburb to major city in } \\
\text { west of Sweden }\end{array}$ & $\begin{array}{l}1 \text { property } \\
\text { manager }\end{array}$ \\
\hline Private & $\begin{array}{l}\text { Central location in } \\
\text { major city in west of } \\
\text { Sweden }\end{array}$ & $\begin{array}{l}1 \text { property } \\
\text { manager }\end{array}$ \\
\hline Private & $\begin{array}{l}\text { Central location in } \\
\text { major city in south of } \\
\text { Sweden }\end{array}$ & $\begin{array}{c}1 \text { energy and } \\
\text { environment } \\
\text { manager }\end{array}$ \\
\hline Public & $\begin{array}{l}\text { Outskirts of major city } \\
\text { in south of Sweden }\end{array}$ & 1 property host \\
\hline Private & $\begin{array}{l}\text { Outskirts of major city } \\
\text { in south of Sweden }\end{array}$ & 2 caretakers \\
\hline Public & $\begin{array}{l}\text { Small city in south of } \\
\text { Sweden }\end{array}$ & $\begin{array}{l}1 \text { property } \\
\text { manager }\end{array}$ \\
\hline Public & $\begin{array}{l}\text { Small city in south of } \\
\text { Sweden }\end{array}$ & $\begin{array}{l}1 \text { property } \\
\text { manager }\end{array}$ \\
\hline
\end{tabular}

\subsection{Simulations}

In order to determine the impact of high residential density on the IAQ and the hygrothermal status of the building materials, simulations were conducted using a model of a Swedish apartment in WUFI Plus [8]. WUFI Plus is a building performance simulation software that can be used in order to determine the energy performance of a building, the indoor climate, and the hygrothermal status of the building materials in the building envelope.

The chosen apartment was built in 1969. The apartment consists of two bedrooms, one living room, one hallway, one kitchen and one bathroom. In the building-performance simulations however, the apartment was modelled as a single zone with no interior walls. The model apartment has a $104 \mathrm{~m}^{2}\left(8.7 \times 11.2 \mathrm{~m}^{2}\right)$ living space area, and the height of the interior walls inside the apartment is $2.7 \mathrm{~m}$. The apartment was chosen for these simulations since its building technology and building services were assumed to be representative of the later part of the million homes programme. In Table 2 , details on the building envelope of the apartment are described based on drawings provided by the property manager. As shown in the table, the simulations assume a relatively vapor-tight surface for the interior and exterior surfaces that are (presumed to be) painted or otherwise (presumed to) have a relatively vapor-tight material (such as linoleum flooring). 
The outdoor climate for the simulations was acquired from METEONORM [9] for the city of Malmö. The simulations included an initialization period of 365 days. Initial indoor temperature was set to $21^{\circ} \mathrm{C}$, initial $\mathrm{RH}$ to $50 \%$ and initial $\mathrm{CO}_{2}$ concentration to $400 \mathrm{ppm}$. The set point for the heating system was set to $21^{\circ} \mathrm{C}$, which is a common temperature provided by building owners according to the interviewees. The ventilation was assumed to be natural ventilation with an assumed constant ventilation rate of $0.5 \mathrm{ac} / \mathrm{h}$, and an infiltration ventilation rate of $0.1 \mathrm{ac} / \mathrm{h}$.

Table 2: Description of the building envelope of the simulated model, as well as some details pertaining to the hygrothermal simulations.

\begin{tabular}{|c|c|}
\hline $\begin{array}{l}\text { Building } \\
\text { component }\end{array}$ & Design (from interior to exterior) \\
\hline Roof & $\begin{array}{l}\text { - } \text { Coating 0.1perm } \\
\text { - } 160 \mathrm{~mm} \text { Concrete } \\
\text { - } 130 \mathrm{~mm} \text { Mineral Wool } \\
\text { - Attic air volume (model: } 120 \mathrm{~mm} \\
\text { ventilated air layer, } \mathrm{n}=1^{*} \text { ac/h) } \\
\text { - } 22 \mathrm{~mm} \text { Tongue-and-groove board (model: } \\
22 \mathrm{~mm} \text { Softwood) } \\
\text { - Asphalt impregnated paper }(60 \mathrm{~min})\end{array}$ \\
\hline $\begin{array}{l}\text { Exterior walls } \\
\text { - load bearing }\end{array}$ & $\begin{array}{l}\text { - Coating 0.1perm } \\
\text { - } 100 \mathrm{~mm} \text { Concrete } \\
\text { - } 100 \mathrm{~mm} \text { Mineral Wool } \\
\text { - } 100 \mathrm{~mm} \text { Limestone (model: Öland), } \\
\text { absorption=0.4, emission=0.9 } \\
\text { - Paint (model: } 0.1 \text { perm, no rain } \\
\text { absorption) }\end{array}$ \\
\hline $\begin{array}{l}\text { Exterior walls } \\
- \text { other }\end{array}$ & $\begin{array}{l}\text { - } 12.5 \mathrm{~mm} \text { gypsum board with aluminium } \\
\text { foil on the exterior (AF modelled as: } \\
\text { vapour retarder sd=100m) } \\
\text { - } 100 \mathrm{~mm} \text { mineral wool between wooden } \\
\text { studs (model: } 100 \mathrm{~mm} \text { mineral wool) } \\
\text { - } 3 \mathrm{~mm} \text { HDF board (wind barrier) } \\
\text { - } 20 \mathrm{~mm} \text { ventilated air layer ( } \mathrm{n}=50^{*} \text { ac/h) } \\
\text { - } 100 \mathrm{~mm} \text { limestone (model: Öland) } \\
\text { - Paint (model: } 0.1 \text { perm, no rain } \\
\text { absorption) }\end{array}$ \\
\hline Windows & 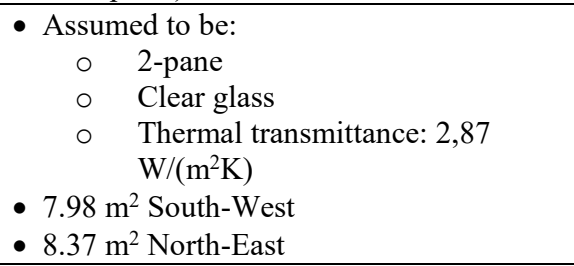 \\
\hline Foundation & $\begin{array}{l}\text { - } \text { Coating 0.1perm } \\
\text { - } 200 \mathrm{~mm} \text { Concrete } \\
\text { - } 150 \mathrm{~mm} \text { Expanded clay aggregate with } \\
\text { cement binder (model: Aerated clay brick) }\end{array}$ \\
\hline
\end{tabular}

The occupancy in the apartment was based on an existing daily schedule for a family of four in WUFI Plus named "Family Household (4 Persons) - Total Weekday". According to the description of this profile, it assumes that three persons are present $17 \mathrm{~h}$ /day and that the household includes 15 plants, two bathrooms, two showers per day, and four laundries in four days, as well as the use of one dishwasher. The schedule includes heat emission through convection and radiation in hourly average $\mathrm{W}$, moisture and $\mathrm{CO}_{2}$ production in $\mathrm{g} / \mathrm{h}$, and human activity in MET (i.e. metabolism: $\mathrm{kcal} /(\mathrm{kg} \cdot \mathrm{h})$ ). According to the description of the profile in WUFI Plus, data for heat emission per person is based on VDI 2078:1996 (DIN 1946-2) [10], and data for other heat sources is based on DIN V 4108-6 [11] and acquired from Nipkow et al. [12]. According to the description, data for the moisture production is according to Künzel [13] and Lutz et al. [14]. Finally, data for the $\mathrm{CO}_{2}$ production is acquired from VDI 4300-7 [15].

In order to simulate an increased occupancy, the loads in the schedule were multiplied in order to match the number of people specified in the following three cases, of which case two and three were described in the interviews:

- Case 1: The nominal case with a family of four, used as given in WUFI Plus.

- Case 2: Based on eight persons in a $80 \mathrm{~m}^{2}$ apartment, i.e. $0.10 \mathrm{p} / \mathrm{m}^{2}$, which in the model apartment corresponds to 10 persons.

- Case 3: Based on five persons in a $26 \mathrm{~m}^{2}$ apartment, i.e. $0.19 \mathrm{p} / \mathrm{m}^{2}$, which in the model apartment corresponds to 19 persons.

A case $3 B$ and was also simulated. This included the impact of a thermal bridge, which was approximated by adding an air layer on the interior of the wall corresponding to an increase of the surface air layer's Rvalue by an additional $0.13 \mathrm{~W} /\left(\mathrm{m}^{2} \mathrm{~K}\right)$, in order to get a lower temperature at the interior surface of the wall.

\section{Results}

\subsection{Semi-structured interviews}

Results from the 11 interviews concerning issues associated with high residential density have been summarized by the authors and grouped based on the type of effect caused (moisture and mould, IAQ, wear and tear, dirt and waste, noise, and consumption), which is described in Sections 3.1.1-3.1.6. Thereafter, these issues have been categorised according to whether they were in fact caused by a high residential density or if they were caused by a certain behaviour of the residents (vertical categorisation, Table 2). These causes were then split up into whether the issue merely stemmed from a high load on the building and its systems or if it stemmed from residents actively interfering with the building and its systems (horizontal categorisation, Table 2 ). These categorisations were conducted as they help separate issues that can be remedied through communication with the residents (e.g. change of behaviour and removal of interference) from those that might require technical adaptions of the building (e.g. altering the building to suffice for a higher load of moisture, wear and tear etc.).

Extreme conditions revealed as examples by the interviewees have been summarized in Table 4 and are used as input data for the simulations. 


\subsubsection{Moisture and Mould (MM)}

Increased shower frequency. Buildings from the million homes programme were designed for the habits of that time. According to several interviewees, it was common to design bathrooms and ventilation systems based on the assumption that each resident showers twice a week. Also according to the interviewees, it is not uncommon that residents today shower once a day. Consequently, even when the residential density is not high, contemporary showering habits contribute to moisture loads that exceed the capacity of the buildings and the bathrooms. Similarly, an increased residential density should result in an increased shower frequency which also increases the moisture loads in the bathrooms. Due to this, many of the interviewees had noted mould growth in the ceiling-wall corner of the bathroom.

Crowded bedrooms. The interviewees described that several people often sleep in the same bedroom in crowded apartments, with examples of up to six persons sleeping in one room. They noted that, due to the excessive generation of moisture, walls were sometimes "almost wet" and that mould in some cases was found in the ceiling-wall corner, especially in cold corners where two external walls and the roof meet. More so, when beds due to crowdedness were placed next to outer walls, moisture damage, grease, and/or mould was sometimes found on the wall next to the bed.

Insufficient drain capacity. A high residential density places a high stress on the drains. One interviewee described that they often had issues with the drains in a high-rise building with eight apartments per floor and 16 apartments per drain.

Clogging of drain. It was described by one interviewee that drains were clogged due to disposal of inappropriate waste in toilets. This was not thought to be a consequence of a high residential density, but rather an issue of behaviour.

Longer cooking times. Some interviewees stated that many households cooked meals for longer time periods, meaning that a simmering pot could be on the stove all day long. Longer cooking times should generate a significant amount of moisture to the air. However, this is more associated with behaviour than residential density - even though a high residential density likely requires more food or larger meals to be cooked in order to feed those residing in the apartment.

Higher cooking frequency. With a higher residential density, food is more likely cooked more frequently than with a low residential density. Interviewees stated that a high residential density leads to more frequent and more extensive cooking. It was also described that cooking was more frequent when several different households lived in the same apartment, since this meant that two or three dinners were cooked separately each night instead of just one. Interviewees noted that this contributed to high moisture loads in the kitchen.
Washing and drying laundry in the apartment. Another source of moisture generation that was brought up by interviewees was the washing and drying of laundry in the apartment. One interviewee described that residents sometimes washed their laundry in the bathtub, and several interviewees had noted laundry hanging to dry in the apartments, sometimes leading to condensation on the windows. This was not thought to be a direct consequence of high residential density, but some interviewees thought that residents in areas with a high residential density had a hard time finding slots in the common laundry room and thus sometimes had to do their laundry in the apartment.

Bathtub removed. It is common to have a bathtub in older apartments. Some interviewees noted that residents prefer to remove the bathtub so that they can stand directly on the floor when showering. However, since bathrooms in Swedish buildings from the million homes programme were not designed for showering, it is not uncommon that the removal of a bathtub leads to water leakage through, or damage to, the bathroom floor. This issue was not thought to be connected to a high residential density.

\subsubsection{Indoor Air Quality}

Additional walls are put up that block airflows. Several interviewees had encountered apartments where additional walls had been put up by the residents to divide rooms into smaller sections that could constitute "bedrooms" for residents. The sectioning of the room was in many cases performed in a way that blocked the airflow from one part of the original room to the other, thus contributing to an impaired indoor environment.

Residents seal fresh air inlet to alleviate issues with draught. Almost every interviewee described that they had extensive problems with residents sealing their fresh air inlets as a means to alleviate issues with draught in the indoor environment. Although this might alleviate such issues, since it also results in a decreased air change rate, it most likely also leads to higher moisture loads and pollutant concentrations. The interviewees noted that this was especially a problem when residents slept near air inlets, which might occur when space is limited in the apartment.

Heavy curtains block the window. Many interviewees described that some residents hung heavy curtains in front of the windows; in some cases to alleviate issues with draught, and in some cases for privacy. The interviewees state that the consequence of this was that mould was often found around the window.

Furniture is placed against windows and outer walls. According to the interviewees, similarly to the issue with heavy curtains, furniture was often found placed close to outer walls, causing mould to grow on the wall. Like the curtains, this is not directly connected to a high 
residential density, however, a high residential density can contribute to an increased amount of furniture which in turn increases the occurrence of furniture being placed close to outer walls.

\subsubsection{Wear and Tear (WT)}

Apartment interior surfaces. Most of the interviewees described that apartment interior-surfaces such as floors, walls, wallpapers, doors, and skirting boards had to be repaired and/or replaced more often when the residential density was high. Several interviewees emphasized that families with many children brought about an especially high wear and tear to the interior surfaces simply due to playfulness among children.

Kitchen white goods. Apart from the interior surfaces, kitchen white goods such as stoves, fridges, and freezers were also described by several interviewees to be exposed to high wear and tear when the residential density was high. The wear and tear were thought to be caused by the more frequent cooking, and one interviewee said that the kitchen white goods had to be exchanged every four years.

\subsubsection{Dirt and Waste (DW)}

Dirtying. Several interviewees described that they had observed issues with dirtying of the apartments. They stated that sometimes there was an accelerated growth of mould on dirty surfaces, and sometimes the dirt caused an increased wear and tear of the apartment interior. Many interviewees were however quick to emphasize that dirtying was not connected to a high residential density as they had observed great differences in dirtying between households of all sizes. Most interviewees thought that the dirtying was more connected to behaviour.

Difficulties to sanitise vermin. Some interviewees noted that a high residential density could be an obstruction when sanitising vermin. This was because sanitation often required cleaning and removal of furniture and belongings from the walls, that could be obstructed by a high number of beds/matrasses. Similarly, the high number of residents and beds/matrasses made it more difficult to evacuate specific rooms for sanitation since the rest of the apartment was not always big enough to fit the beds/matrasses for everyone in the household.

Accumulation of waste and bulky waste in staircases. Several interviewees mentioned problems associated with the high generation of waste that follows a high residential density. Most common among the issues was the accumulation of waste and bulky waste in staircases, which besides contributing to a messy appearance constitute a fire hazard and a hindrance in case of evacuation. While a high residential density contributes to a high generation of waste, it also lays in the behaviour whether the waste is disposed properly or not.

\subsubsection{Noise $(N)$}

Disturbing noises from neighbours. Several interviewees described that they received complaints regarding disturbing noises from neighbours. The noises could be from running (often by playing children) or from arguments, but it was also stressed by interviewees that there were great differences among households, where some crowded households generated a lot of noise and others not. Moreover, there were also differences in whether noises were perceived as disturbing or not.

Table 3. Categorisation and summary of issues caused by high residential density and behaviour, noted in the interviews.

\begin{tabular}{|c|c|c|}
\hline & High residential density & Behaviour \\
\hline 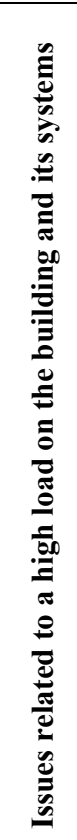 & $\begin{array}{c}\text { MM - Increased shower } \\
\text { frequency } \\
\text { MM - Crowded bedroom } \\
\text { MM - Insufficient drain } \\
\text { capacity } \\
\text { MM - Higher cooking } \\
\text { frequency } \\
\text { MM - Washing and } \\
\text { drying laundry } \\
\text { WT - Apartment interior } \\
\text { WT - Kitchen white } \\
\text { goods } \\
\text { DW - Difficulties to } \\
\text { sanitise vermin } \\
\text { DW - Accumulation of } \\
\text { waste } \\
\text { C - High use of water } \\
\text { N - Disturbing noises } \\
\text { from neighbours }\end{array}$ & $\begin{array}{c}\text { MM - Increased shower } \\
\text { frequency } \\
\text { MM - Clogging of drain } \\
\text { MM - Longer cooking } \\
\text { times } \\
\text { MM - Washing and } \\
\text { drying laundry } \\
\text { WT - Apartment interior } \\
\text { WT - Kitchen white } \\
\text { goods } \\
\text { DW - Difficulties to } \\
\text { sanitise vermin } \\
\text { DW - Dirtying } \\
\text { DW - Accumulation of } \\
\text { waste } \\
\text { C - High use of water } \\
\text { N - Disturbing noises } \\
\text { from neighbours }\end{array}$ \\
\hline 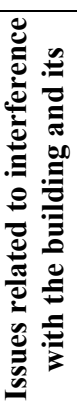 & $\begin{array}{l}\text { IAQ - Additional walls } \\
\text { are put up } \\
\text { C - Residents install } \\
\text { extra appliances } \\
\text { IAQ - Furniture placed } \\
\text { against exterior walls }\end{array}$ & $\begin{array}{l}\text { MM - Clogging of drain } \\
\text { MM - Bathtub is } \\
\text { removed } \\
\text { IAQ - Residents seal } \\
\text { ventilation } \\
\text { IAQ - Heavy curtains } \\
\text { IAQ - Furniture placed } \\
\text { against exterior walls }\end{array}$ \\
\hline
\end{tabular}

\subsubsection{Consumption (C)}

Residents install extra appliances. Some interviewees had observed that households with a high residential density installed extra appliances such as white goods and washing machines in order to adjust the apartment to the high residential density. One interviewee even described a case where an extra kitchen had been installed in one apartment. The extra appliances are likely to contribute to an increased use of electricity, water and moisture load.

High use of water. Many interviewees described that they thought there was a correlation between water use 
and number of residents. One interviewee who worked in an area with high residential density knew for a fact that the area had the highest water use in the city. Most interviewees described that water use was not measured per household in the area they worked in, but many considered individual metering and billing of water to be a promising method to reduce the water use.

Table 4. Extreme situations revealed as examples by the interviewees.

\begin{tabular}{|c|c|c|}
\hline Extreme situation & Consequences \\
\hline $\begin{array}{c}\text { Dwelling/ } \\
\text { sleeping }\end{array}$ & $\begin{array}{c}15 \text { persons at } 57 \mathrm{~m} 2 \\
8 \text { persons at } 80 \mathrm{~m} 2 \\
2+3 \text { persons at } 26 \mathrm{~m} 2 \\
6 \text { persons in one room }\end{array}$ & $\begin{array}{c}\text { Excess moisture, } \\
\text { Condensation, } \\
\text { Mould growth, } \\
\text { High CO2 } \\
\text { Blocked ventilation }\end{array}$ \\
\hline Shower & $\begin{array}{c}4 \text { persons shower } \\
\text { every morning, } \\
1 \text { person showers } 45 \\
\text { min } \\
\text { Hot steam bath every } \\
\text { Sunday }\end{array}$ & $\begin{array}{c}\text { Excess moisture, } \\
\text { Leakage, } \\
\text { High DHW } \\
\text { consumption }\end{array}$ \\
\hline Laundry & $\begin{array}{c}\text { Frequent cooking } \\
\text { Frequent washing and } \\
\text { drying laundry }\end{array}$ & $\begin{array}{c}\text { Excess moisture } \\
\text { condensation on } \\
\text { windows }\end{array}$ \\
\hline
\end{tabular}

\subsection{Simulations}

Results from simulations in WUFI Plus show that increased residential densities result in increased $\mathrm{RH}$ in the indoor air as well as on interior surfaces. As shown in Figure 2 and Table 5, with a density of more than four persons in a two-bedroom apartment, the $\mathrm{RH}$ in the indoor air exceeds $75 \%$ for a significant number of hours annually, in all cases, and this number is increased with the increasing residential density. It must be noted that although it might seem as if the RH in the indoor air is constantly at $100 \%$ with a density of 19 persons in Figure 2, this is not the case, as clarified by Figure 1 and Table 5. Furthermore, Table 5 shows that the number of hours during which the $\mathrm{RH}$ in the indoor air exceeds $99.9 \%$ also increases with the residential density, entailing an increased risk for condensation on interior surfaces.

Figure 4 and Table 6 show that the hourly average $\mathrm{RH}$ at $5 \mathrm{~mm}$ from the interior surface of the gypsum board exceeds $75 \%$ for a significant number of hours per year in all cases. Table 6 also shows how often the 12hour average RH on the interior surface of the gypsum board exceeds $75 \%$. This frequency also increases with the residential density, which means that the number of consecutive hours during which there is a risk for microbiological growth increases as well. Furthermore, simulations in case $3 \mathrm{~B}$ show the issue is amplified at interior surfaces at thermal bridges, such as at joints between facades and slabs, or between exterior walls elements. In such places the $\mathrm{RH}$ on the interior surface of the gypsum board exceeds $75 \% 7539$ hours (643 no. of 12-hour periods) annually, but that no condensation occurs.

Results in Figure 2 and Table 5 show that increased residential densities also result in increased $\mathrm{CO}_{2}$ concentrations, which indicates that the IAQ is diminished. As shown in Table 5, with a density of 10 persons in the simulated apartment the $\mathrm{CO}_{2}$ concentrations exceed $1000 \mathrm{ppm}$ for more than 5841 hours annually, and with 19 persons $1000 \mathrm{ppm}$ is exceeded 8031 hours annually.

Finally, Table 5 also shows that the number of hours during which the indoor air temperature exceeds $26^{\circ} \mathrm{C}$ increase with the residential density, which should result in a diminished thermal comfort in the apartment.

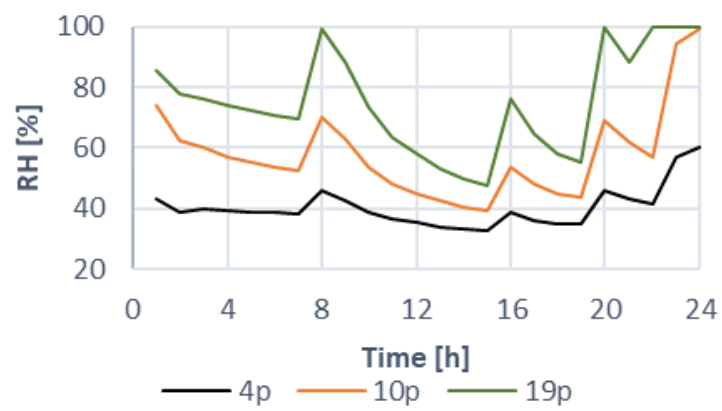

Figure 1. Resulting RH in the indoor air with different residential densities, during the first day of simulation. Lines: black $=$ case 1 , orange $=$ case 2 , green $=$ case 3 .

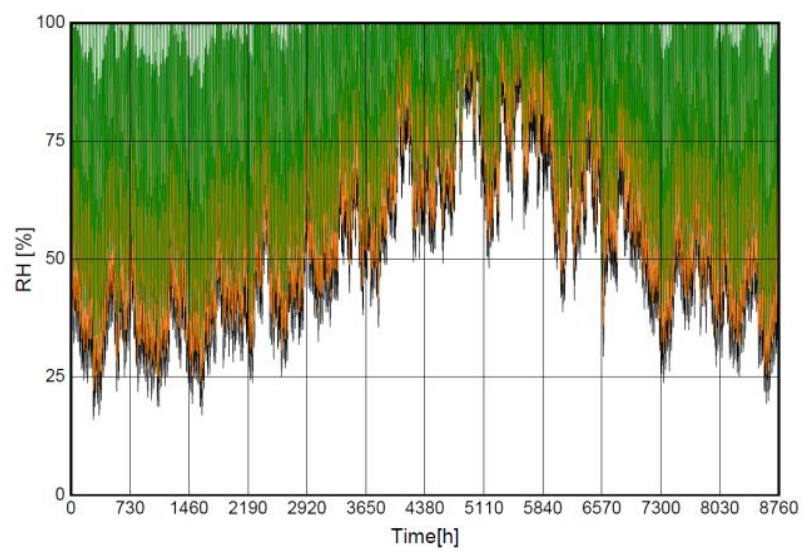

Figure 2. Resulting RH in the indoor air with different residential densities. Lines: black $=$ case 1 , orange $=$ case 2 , green $=$ case 3 .

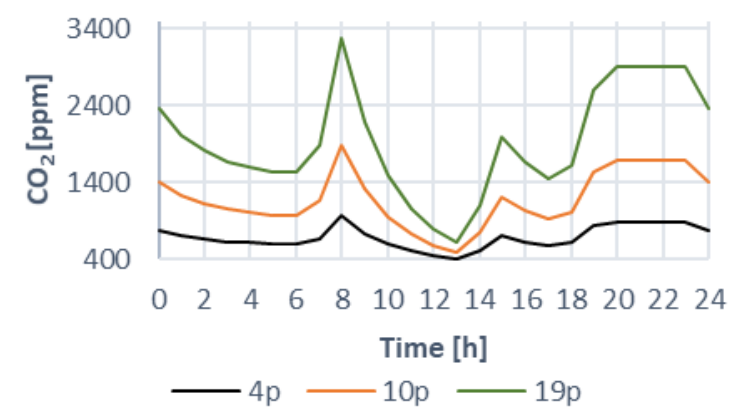

Figure 3. Resulting $\mathrm{CO}_{2}$ concentrations during a day (24h).

Table 5. Annual sum of hours during which parameters in the indoor air are exceeded. 


\begin{tabular}{|c|c|c|c|c|}
\cline { 2 - 5 } \multicolumn{1}{c|}{} & \multicolumn{4}{c|}{ Time $[\mathbf{h}]$} \\
\hline Case & $\begin{array}{c}\mathbf{T}> \\
\mathbf{2 6}^{\circ} \mathbf{C}\end{array}$ & $\begin{array}{c}\mathbf{R H}> \\
\mathbf{7 5 \%}\end{array}$ & $\begin{array}{c}\mathbf{R H}> \\
\mathbf{9 9 . 9 \%}\end{array}$ & $\begin{array}{c}\mathbf{C O}_{2}> \\
\mathbf{1 0 0 0} \mathbf{p p m}\end{array}$ \\
\hline $1 / 4 \mathrm{p}$ & 0 & 887 & 13 & 0 \\
\hline $2 / 10 \mathrm{p}$ & 0 & 2940 & 446 & 5841 \\
\hline $3 / 19 \mathrm{p}$ & 138 & 5545 & 1638 & 8031 \\
\hline
\end{tabular}

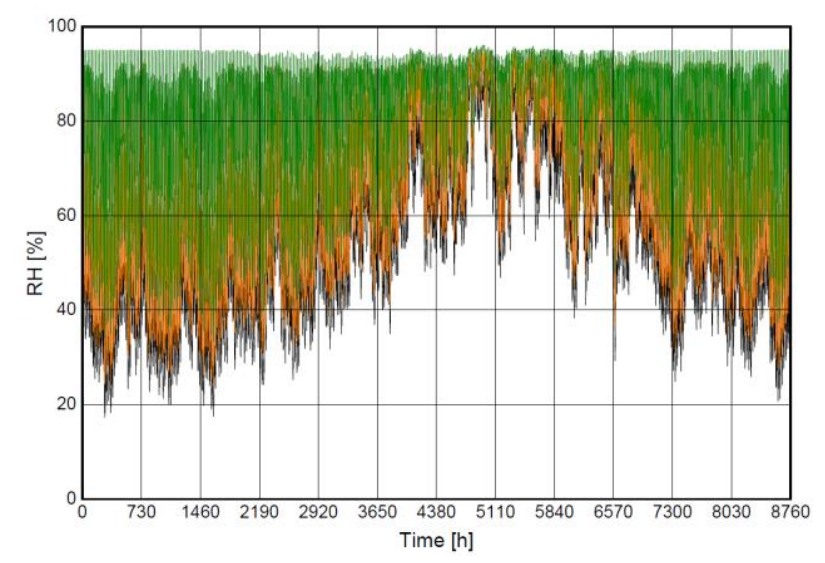

Figure 4. Resulting RH $5 \mathrm{~mm}$ from the surface of the gypsum board with different residential densities during a year of simulation. Lines: black $=$ case 1 , orange $=$ case 2 , green $=$ case 3 .

Table 6. Time during which $75 \% \mathrm{RH}$ is exceeded at $5 \mathrm{~mm}$ from the surface of the gypsum board.

\begin{tabular}{|c|c|c|}
\hline Case & $\begin{array}{c}\text { Time }[\mathrm{h}] \\
\text { RH } \mathrm{hourly} \mathrm{average}>75 \%\end{array}$ & $\begin{array}{c}\text { Time [No. of } 12 \mathrm{~h}- \\
\text { periods] } \\
\text { RH }_{12 \mathrm{~h} \text { average }}>75 \%\end{array}$ \\
\hline $1 / 4 p$ & 847 & 64 \\
\hline $2 / 10 p$ & 3072 & 182 \\
\hline $3 / 19 p$ & 6012 & 509 \\
\hline
\end{tabular}

\section{Discussion}

In Sweden, the government has the ultimate responsibility to ensure sound and healthy housing for all, not resulting in unreasonably high residential density in parts of the housing stock. However, the current situation with housing shortage and a lack of affordable housing cannot be solved in a quick way, and high residential density will most likely remain in parts of the housing stock during many years to come. The results from the simulations, which are based on extreme examples from the interviews, show that the current situation of high residential density in some cases leads to high levels of RH and condensation. This is confirmed by observations from interviewees who had seen condensation and mould in resident-dense apartments. However, one result from the simulations that was not known from the interviews was that the $\mathrm{CO}_{2}$ concentrations in these cases exceed the conventionally accepted Pettenkoefer limit (1000 ppm) to the extent that it could become a health risk. Therefore, it is important to increase knowledge about measures that can help assure an adequate indoor environment for the residents and minimise the risk of damage to the building in resident-dense areas.

As suggested by the results in Table 3, most problems associated with a high residential density are directly linked to the high load that the residents pose on the building and its systems. Only in a few cases are problems caused by interfering adjustments made by the residents. More so, many problems associated with a high residential density are also associated with behaviour, meaning that the behaviour of the residents can reduce or aggravate the issues, and high residential density does not always have to be the cause of these problems. Consequently, depending on the type of problem, there can either be technical or behavioural solutions. Based on the interviews and the analyses, a number of possible measures to manage the indoor environment during high residential density are suggested. The measures are sorted based on whether they are of technical or of communicative and behavioural character.

Technical measures. The issues listed as caused by a high residential density and the subsequent high load on the building (upper left square in Table 3 ) are issues that require technical adjustments of the building in order to ensure an adequate indoor environment and minimise damage to the building and its materials.

To reduce condensation, the building envelope could be insulated to reduce thermal bridges due to bad insulation. Gables, attics, corners, fixings, connections and joints are parts of the structure with poor insulation and thermal bridges. To reduce $\mathrm{RH}$ and $\mathrm{CO}_{2}$ concentrations, proper ventilation systems could be installed with, if possible, demand control ventilation and heat recovery. More so, air inlets should be designed and placed to allow for furnishing close to the outer wall without causing condensation. Other measures could be to install water-saving nozzles which should reduce the amount of water introduced to the indoor air and thereby reduce the moisture loads.

To reduce wear and tear, durable interior materials should be chosen, for example paint instead of wallpaper and good quality interior doors and cabinet doors. Finally, while monitoring of temperature is frequently done by the housing companies, it could also be of interest to monitor $\mathrm{RH}$ and $\mathrm{CO}_{2}-$ especially in bedrooms. The property manager would thus be informed when RH exceeds $75 \%$ (risk for microbial growth) and when $\mathrm{CO}_{2}$ concentrations risk having a negative impact on the residents' health and well-being. This would allow the property manager to take action and help remedy the poor indoor environment.

Communicative and behavioural measures. The issues listed as caused by behavioural patterns of the residents could, at least to some extent, be remedied by communicating with and informing the residents. Likewise, issues listed as caused by interventions by the residents could be remedied by informing them and in some cases by providing a better solution to the problem the residents are trying to solve themselves. 
For example, the results from the interviews revealed that it was common that residents blocked air inlets to remove cold draught. By informing the residents of the importance of having the air inlets open, the ventilation could be improved. This communication is facilitated by a good relation between the housing caretaker and the tenants, and a good relation also comes with benefits such as quick feedback in case of errors or problems. More so, it is of great importance to create an understanding of the functions of the apartment and its systems (ventilation, drainage, kitchen exhaust fan) but also advise on opening windows for ventilation, furnishing, curtain sets, cooking procedures, fat separation, food storage, waste handling, sewage treatment, cleaning and drying of laundry. The best way is to give such instructions and advise to the tenants in their own apartment. Finally, informing residents on the importance of a frequent and well-organized handling of bulky waste can be an effective solution to avoid the feeling of untidy environments and insecurity, but also to decrease the risk of fire in staircases.

Hygrothermal simulation results. By using the occupancy profiles in WUFI Plus, the impact of high residential density on the RH was possible to determine. However, it must be noted that the results are in hourly averages values, which means that the impact of events occurring with shorter time intervals are not shown. This could be one of the reasons to why the results for the RH in the indoor air suggests that condensation occurs, while it appears as if no condensation occurs by the surface of the gypsum board. Another reason is that the gypsum board has a moisture capacity far larger than the indoor air and that it must have a moisture content corresponding to $100 \% \mathrm{RH}$ for condensation to appear. This, since in transient hygrothermal calculations the RH in the pores of a material is coupled to the moisture content of a material. Another thing that is noticeable is the decreased fluctuations in the $\mathrm{RH}$ at higher $\mathrm{RH}$ $(>85 \%)$. A reason for this is that increments in $\mathrm{RH}$ at higher $\mathrm{RH}$, for many building materials, will require larger amounts of moisture.

\section{Conclusions}

The results show an increased risk for $\mathrm{CO}_{2}$ concentration above the recommended level as well as RH levels favourable for mould growth in typical apartments from the million homes programme with natural ventilation and residential densities higher than a family of 4 people at $100 \mathrm{~m}^{2}$. The results could be used by authorities to formulate incentives and/or recommendations for housing owners to implement measures such as applicable ventilation technology that improves the IAQ and ensure a good indoor quality for all, irrespective of residential density conditions.

This research was funded by the Swedish Energy Agency, program E2B2 grant 41819-1, NOVA.

\section{References}

1. Allmännyttan. 1946-1975 Allmännyttan Byggs ut och Bostadsbristen Byggs Bort.

https://www.allmannyttan.se/historia/historiskaepoker/1946-1975-allmannyttan-byggs-ut-ochbostadsbristen-byggs-bort/

(Accessible: 2020-01-16)

2. Boverket, 2009. Så mår våra hus. https:/www.boverket.se/globalassets/publikationer/ dokument/2009/sa mar vara hus.pdf

(Accessible: 2020-01-16)

3. T.A. Jacobson, J.S. Kler, M.T. Hernke, et al. Direct human health risks of increased atmospheric carbon dioxide. Nat Sustain 2, 691-701 (2019) doi:10.1038/s41893-019-0323-

4. T.A. Markus. Cold, condensation and housing poverty. In: Burrage R, Ormandy D, eds. Unhealthy Housing Research Remedies and Reform. New York, NY Spon Press; 1993:141-167. (1993)

5. Sedlbauer, K., 2002. Prediction of mould growth by hygrothermal calculation. Journal of Thermal Envelope and Building Science, 25(4), pp.321-336.

6. Boverket, 2006. Var finns rum för våra barn? - en rapport om trångboddhet i Sverige.

https://www.boverket.se/globalassets/publikationer/ dokument/2006/var_finns_rum-for_vara_barn.pdf (Accessible: 2020-01-16)

7. K. Mjörnell, D. Johansson, H. Bagge. The Effect of High Occupancy Density on IAQ, Moisture Conditions and Energy Use in Apartments. Energies (2019).

8. WUFI Plus 3.1 Manual, https://wufi.de/de/wpcontent/uploads/sites/9/2017.07_WUFI-PlusManual_en.pdf. (Accessible: 20י-01-10)

9. Meteonorm. https://meteotest.ch/en/product/meteonorm (Accessible: 2020-01-13)

10. VDI 2078:1996-07. Cooling load calculation of airconditioned rooms (VDI cooling load regulations)

11. DIN V 4108-6:2003-06. Thermal protection and energy economy in buildings - Part 6: Calculation of annual heat and energy use.

12. Nipkow Jürg, Gasser Stefan, Bush Eric, 2007. Der typische Haushalt-Stromverbrauch. HEA Fachgemeinschaft für effiziente Energieanwendungen e.V. 2011 und Quelle. Bulletin SEV/VSE 19/2007

13. Künzel, H., 2009. Wohnungslüftung und Raumklima.

14. Lutz, P., Jenisch , R., Klopfer , H., Freymuth , H., Petzold , K., Stohrer , M. 2002. Lehrbuch der Bauphysik. Springer-Verlag.

15. VDI 4300-7:2001. Indoor-Air Pollution Measurement - Measurement of Indoor Air change rate. 